\title{
What May Library and Information Science Offer to Personal Information Management?
}

\author{
Zbigniew Gruszka \\ ORCID 0000-0002-7834-3893 \\ Department of Information, Library and Book Studies, Faculty of Philology \\ University of Lodz, Poland
}

\begin{abstract}
Purpose/Thesis: The development of personal information management (PIM) suggests a new area of interest for library and information science (LIS) practitioners and researchers. Basing on the research the article investigates the application of technological solutions for PIM in LIS.

Approach/Methods: In the presented research, the critical analysis of the literature was used to explain the relationship between PIM and LIS and to prepare an empirical study focused on the perception of the usefulness of PIM tools in the area of LIS practice and research. The empirical study was conducted with a mixed methodology encompassed both quantitative and qualitative methods. Results and conclusions: The analysis showed that the solutions offered by the LIS practitioners and researchers in the field of PIM have already been correctly defined. Some initiatives in the field of open access, digitization of collections, modernization of integrated library systems or the implementation of ICT in education are already being implemented. However, LIS practitioners and researchers are primarily perceived as offering high-quality, verified and truthful information accessible through applications, digital platforms and other modern technological solutions.

Originality/Value: Presented results may inspire LIS practitioners and researchers to further development of the offer of their institutions.
\end{abstract}

Keywords

Library and information science. Personal information management. Students' expectations.

Received: 7 June 2019. Reviewed: 8 September 2019. Revised: 31 March 2020. Accepted: 28 April 2020.

\section{Introduction}

Library and information science (LIS) which as a part of the discipline in Poland is called "bibliology and informatology" (book science and information science) and till 2018 was classified as a humanistic discipline, has been increasingly moving towards social sciences. In the new official classification of scientific fields and disciplines in force in Poland since the end of 2018, LIS has been formally qualified for social sciences - this time as a part of the communication and media studies. It should be noted that since some time, the LIS research in Poland has already been focused on social research of micro- and macro-environment - libraries, information users, book culture, reading, the Internet, or different aspects of information and knowledge society. However, not enough attention has been paid to the information user as a person. The issue of information and knowledge management has received some consideration, also from the perspective of the individual, not sooner than 
at the beginning of the 21st century, mainly owing to works by Jacek Tomaszczyk (2008), Katarzyna Materska (2012), or Marzena Świgoń (2012). The relations between personal information management and knowledge organization have been recently described by Remigiusz Sapa (2014, 2016a, 2016b) and Barbara Sosińska-Kalata (2016).

\section{Methodology}

The article investigates the application of technological solutions to personal information management (PIM) in LIS. The need for an analysis and description of these solutions became clear after reading articles devoted to PIM. These works, proving the usefulness of the proposed tools (see Thint et al., 2003), led the author to believe that an analogous claim can be made regarding LIS subdisciplines, in each area whose the user can expect a technological solution (website, application) improving their personal knowledge management. This perspective, based on interdisciplinary relationships, which is present in the research on PIM (Julien \& Duggan, 2000, 296; Materska, 2012, 68) allowed to compile a list of proposals for expanding the research field of subdisciplines of LIS, based on the thematic categorization found in the literature on the discipline (Materska, 2008; Sosińska-Kalata, 2007).

The collected proposals were then revised to account for the opinions of the respondents who have taken part in the qualitative and quantitative research, declaring whether they believed the proposed solutions to be founded and useful.

\section{Personal information management}

William Jones, considered to be the creator and propagator of the PIM theory, states that although in practice everyone manages the information individually, defining PIM is difficult (Jones, 2007, 463). Citing an article by Mark Lansdale $(1988,55)$, the first researcher who used the term "personal information management", he defines it as

the methods and procedures by which we handle, categorize and retrieve information on a day-byday basis.

Jones goes on to quote Bellotti et al. (2002), according to which PIM is understood as

the ordering of information through categorization, placement, or embellishment in a manner that makes it easier to retrieve when it is needed (Bellotti et al., 2002, 182).

PIM is traditionally associated with different processes, to which the information is subject. In his chapter published in Annual Review of Information Science and Technology, Jones wrote that PIM

refers to both the practice and the study of the activities a person performs in order to acquire or create, store, organize, maintain, retrieve, use, and distribute the information needed to complete task (work-related or not) and fulfill various roles and responsibilities (for example, as parent, employee, friend, or community member) (Jones, 2007, 453).

Thus, PIM is a practical activity, with the user managing the collection of personal information independently and using the tools known to him, but it refers to the study of 
the systems supporting these processes in the broadest possible sense. It should be noted that creation, storage, organization, preservation, retrieval, or mere use of information in a technologically dominated world, with different intentional goals and expertise of users constitute an extensive topic that cannot be exhausted in one work.

The academic interest in PIM dates back to 1980s. Lansdale used this concept in a work titled The Psychology of Personal Information Management in 1988, however according to Jones and Świgon it was developed in the years following World War II, when the usefulness of machines supporting automatic information processing was noticed (Jones 2007; Świgoń, 2012). In the 1960s, with the development of computers, various researchers noticed that computers can not only increase people's ability to process information, but even "enhance human intellect" (Jones 2007).

An analysis of the literature on PIM conducted in 2010 by researchers using the Google Scholar search engine to determine the number of responses to the search query "personal information management" showed nearly 6000 hits. After selecting the most often cited works since 2008, this has been narrowed down to a still considerable number of 558 hits (Stenmark et al., 2010). The study of PIM is, as demonstrated, increasingly pursued by researchers from various fields of knowledge. Currently (in November 2019), Google Scholar returns as many as 33500 hits. More and more attention is devoted to advanced methods and tools that support and improve self-management of information.

Current research in the area of PIM - taking into consideration the broad scope of the subject - is conducted through various lenses and investigates widely understood activities such as:

- finding;

- keeping;

- further meta-level activities such as:

- organizing;

- maintaining;

- managing privacy and a flow of information;

- measuring and evaluating;

- making sense of information (Świgoń 2012, 195).

The most important thematic fields in PIM research are as follows:

- information behavior, organization and research models (Barreau, 2008; Case \& Given, 2016; Courtright, 2007; Sapa, 2016a; 2016b) also regarding on social context (Shah, 2017);

- data protection and security (Batorowska, 2018; Cate 2010; Marx, 2007);

- information trustworthiness (Mollick, 2010);

- information tools, technologies (Bernstein et al., 2008; Cushing, 2010) and applications (Stenmark et al., 2010; Thint et al., 2003).

\section{Library and information science and its subdisciplines}

A thorough exploration of the definition of LIS goes beyond the scope of this article. For the purpose of this study, the definition from the ALA glossary was accepted: 
the knowledge and skill by which recorded information in all formats is selected, acquired, organized, and utilized in meeting the information demands and needs of a community of users. Sometimes called information science, information and library science, and library and information science (Carter \& Levine-Clark, 2013, 154).

Materska is right in saying that:

research areas of information science are constantly changing, and it is impossible to assign to or impose on the information science strict limitations as to the subject it deals with. Scientific information is defined by problems in the context of communicating knowledge and methods used to solve them (Materska, 2008, 35) ${ }^{1}$.

The analysis of the most popular topics discussed in the specialist literature indicates the interests of the authors writing on LIS. In the research by Barbara Sosińska-Kalata, focused on the topics of papers published in the international and Polish journals recognized as the most important in information science, the following list of thematic categories was established:

(1) Information Users. Information behaviors. Use of information. Information sociology.

(2) Method of knowledge organization and representation.

(3) Communication. Information network management. Cooperation. Knowledge transfer.

(4) Models and methods of searching information.

(5) Information theory. General issues.

(6) Designing information systems.

(7) Information and knowledge management.

(8) Information policy. Information law.

(9) Information processing. Generating, recording, archiving, distributing.

(10) Natural language processing (NLP). Computational linguistics.

(11) Bibliometrics. Informetrics. Webometrics. Scientometrics.

(12) Information business. Information economy.

(13) Intelligent systems.

(14) Libraries. Activity. Application of ICT.

(15) Digital libraries.

(16) Reading.

(17) Bibliography.

(18) Educating librarians and information workers. Profession of a librarian and information worker.

(19) Publishing market.

(20) Sources of information (Sosińska-Kalata, 2007, 109-113).

In another research conducted by Spanish scientists on a larger data sample encompassing the entire LIS domain, there was created a list of 150 most common descriptors in the descriptions of 11000 articles published in journals indexed in the LISA database (Gonzáles-Alcaide et al., 2008). Analyzing this list the authors identified three main research areas: World Wide Web, libraries and education (Gonzáles-Alcaide et al, 2008, 152;

\footnotetext{
${ }^{1}$ Own translation $[\mathrm{ZG}]$.
} 
see also: Materska, 2008, 23). A list of 30 most popular descriptors referred to in Table 1, constitutes a detailed characteristic of said areas.

Tab 1. Frequency of occurrence of the keywords in papers indexed in the LISA database in the years 2004-2005 (first 30 keywords with the highest frequency).

Source: Gonzáles-Alcaide et al. (2008)

\begin{tabular}{|c|c|c|c|}
\hline Keyword & Frequency & Keyword & Frequency \\
\hline World Wide Web & 892 & Information technology & 424 \\
\hline Computer application & 736 & Information Communications & 418 \\
\hline Online information retrieval & 686 & Libraries & 417 \\
\hline Medicine & 622 & Healthcare & 415 \\
\hline Networks & 620 & Public libraries & 411 \\
\hline University librarians & 598 & Library materials & 389 \\
\hline Surveys & 567 & Education & 370 \\
\hline Searching & 520 & Academic libraries & 368 \\
\hline Internet & 506 & Artificial intelligence & 362 \\
\hline Evaluation & 492 & Articles & 351 \\
\hline Electronic media & 473 & Research & 321 \\
\hline Users & 453 & Digital libraries & 317 \\
\hline Periodicals & 455 & Information work & 317 \\
\hline Web sites & 434 & Computer assisted instruction & 316 \\
\hline Students & 428 & Publishing & 315 \\
\hline
\end{tabular}

The described lists of thematic categories and the most popular keywords in LIS literature were used as the basis for identification LIS areas in which PIM tools may be applied and developed.

\section{Research}

The main PIM trends indicated in the work, identified as thematic categories of this domain, are closely related to the on-going digital revolution. In the next part, the users' expectations regarding new technologies, which can be implemented in the LIS area, will be presented.

\subsection{Research aims}

The research was aimed to collect the participants' proposals of solutions in the PIM field related to the subdisciplines (areas of knowledge expressed by keywords) of LIS and to characterize and divide them into groups. 


\subsection{Data collection}

The empirical research was conducted with a mixed methodology encompassed both quantitative and qualitative methods. The quantitative approach was used to collect the list of most popular tools utilized by the respondents and to set together these tools which are less used. The qualitative approach was used to gather the ideas of the participants and to describe their perception of PIM. The research was conducted in April 2019 on a sample of 67 students of BA and MA LIS studies at the University of Lodz, Poland.

The participants of the study answered a four-question questionnaire regarding:

- the assessment of the respondent's awareness of new technologies;

- the tools used daily to manage information;

- widely known tools (platforms, solutions, services, devices) that improve personal information management, which the respondent knows but do not use;

- a request to propose and briefly elaborate on an idea for three tools that could improve PIM in the field of LIS, including all known technological solutions available on the market.

In the last question, 20 thematic categories of LIS research were given as a guide. Based on these categories, the survey allowed to find areas in which, according to the respondents, solutions benefitting information users could be proposed.

The same number of students from the first and second year of BA studies (23 persons each) took part in the study. Twelve respondents were in the third year of BA studies and nine were in the first year of MA studies (Fig.1).

Almost three-quarters of respondents were women (76\%, N=67). Sixteen men (24\%) took part in the research.

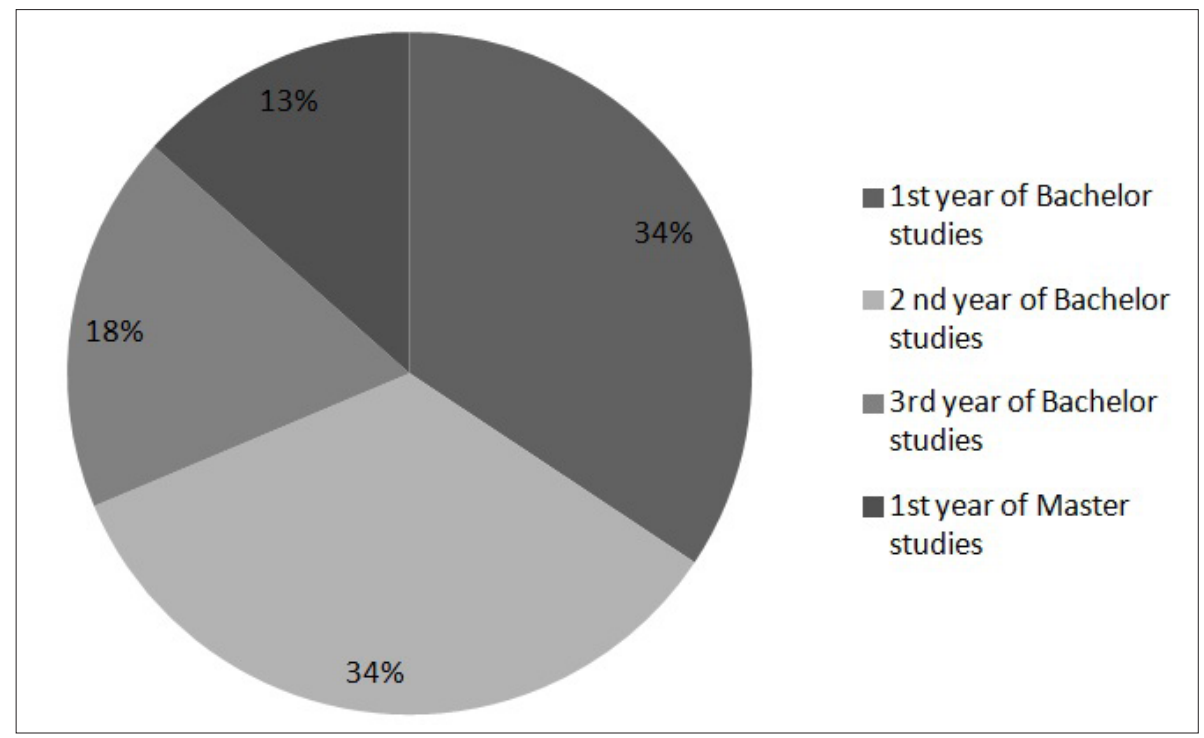

Fig. 1. The distribution of respondents by the year of studies $(\mathrm{N}=67)$ 


\section{Findings}

In the survey, the respondents were asked about the assessment of their skills in the field of new technology. On a five-point scale (from the very high to the very low grade) the responses were almost equally distributed between average and high and very high scores. Exactly $52 \%$ of participants declared that their knowledge of the field was average, $43 \%$ said that it was high, and $1 \%$ - that it was very high; $3 \%$ of the respondents did not answer the question (see Fig. 2).

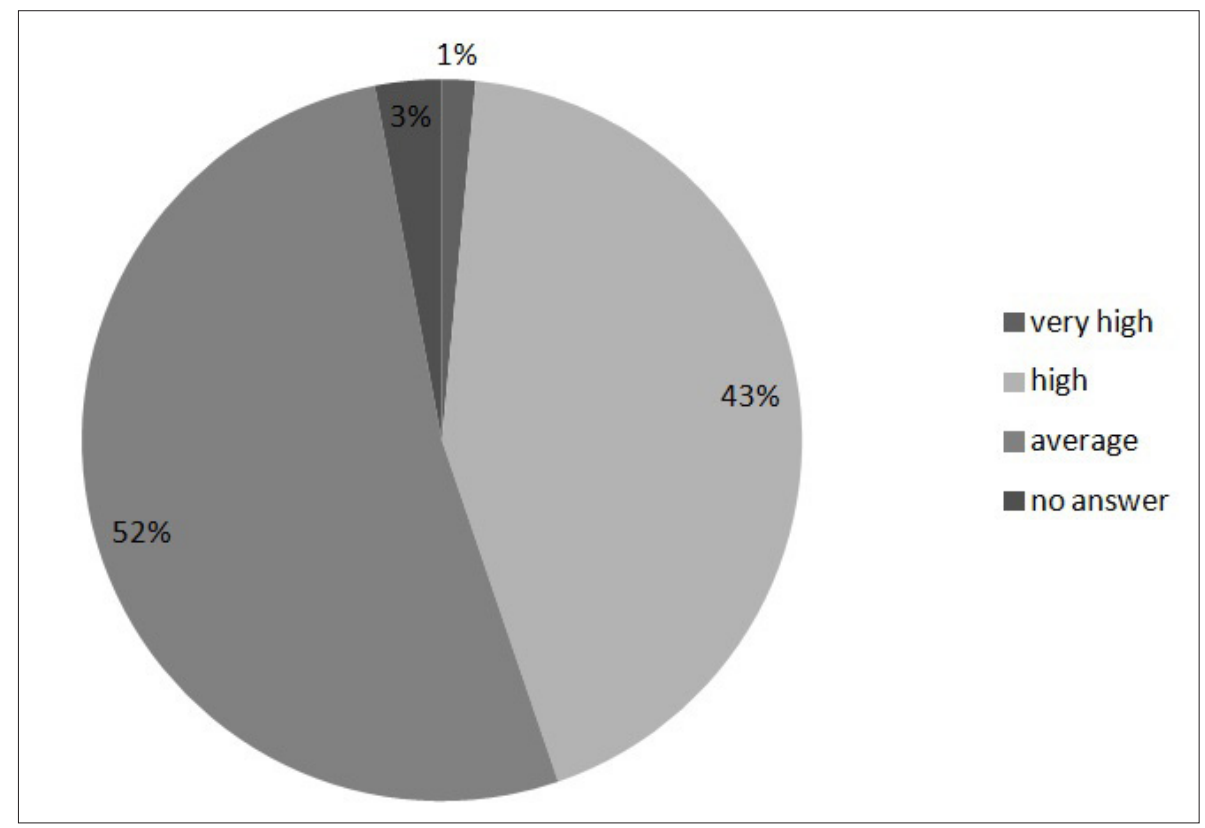

Fig.2. The assessment of respondents' knowledge in the field of new technologies ( $N=67)$

Although the concept of new technologies may have been understood in various ways, the participants' self-assessment of skills was compared with the data collected in question 2 of the survey. The analysis of the number of answers shows that every third respondent was able to list three or four tools (37\%); $27 \%$ of respondents listed five or six; $21 \%$ of participants listed seven or more. Only $15 \%$ answered giving one or two names of tools used to manage information. Although excessive auto-criticism or over-estimation of the respondents' knowledge cannot be ruled out, further analysis has shown a high understanding on the tools (platforms, solutions, services, devices) used for the personal information management.

The collected data proved that the research group included persons familiar with new technologies, and that the majority of them had at least average and higher awareness of the subject.

The analysis of the most frequently used tools for managing information listed by the respondents indicated that they were dominated by Google's applications such as Google 
Calendar, Google Drive, Google Maps, Google Scholar, Google Assistant, Gmail. They were indicated 30 times. However, the participants of the survey also included persons who did not use Google services.

The most popular tool turned out to be an electronic calendar (without specifying the name of the company), which was indicated 27 times and an electronic notebook (18 times). For 21 persons (31\% of respondents), the information management tool was a smartphone, and for 18 of them (27\%) - a computer. Other mobile applications enabling the banking services, providing information on health, weather, facilitating time management, helping to create a list of tasks, handling e-mails and supporting collective work were used by every fourth participant (22\%, 15 persons). The tools generally used for storing data in the cloud, task scheduling programs, e-mail and public transport websites supporting travel planning by public transportation were less commonly mentioned. The storage of data in the cloud was mentioned by nine respondents (16\%), the remaining tools - by five persons (7\%). Further responses appeared in the questionnaire no more than four times. There were among them not only innovative tools for information management, such as SIRI, Alexa synthesizers, smartwatch or TV, but also traditional solutions (a library, paper calendar, sticky notes) and unusual ones (a pendrive, computer folders, a calculator). The full set of answers provided in the question is included in Table 2.

In the next question, the participants were asked to indicate the names of tools (platforms, solutions, services, devices) for PIM, which they do not use, but are aware of. In general, more differentiated answers were provided. The total number of individual responses was significantly lower than the number of declarations of the daily use of tools mentioned by respondents. The most frequently mentioned non-used tool was the software for saving notes (seven responses) as well as data clouds and bibliography managers (six answers each).

Some of the provided answers mentioned the reasons behind a decision not to use a certain tool. Respondents declared that they would not use the services of companies monitoring media and information and infobrokers; single responses concerned the declaration of the non-use of catalogs and library platforms, Microsoft Office and the NUKAT catalog (the Polish union library catalog for academic and research libraries).

Tab. 2. The list of tools for personal information management most often used

by respondents $(\mathrm{N}=67)$; the respondents could give more than one answer

\begin{tabular}{|c|l|c|l|}
\hline $\begin{array}{c}\text { Number } \\
\text { of answers }\end{array}$ & \multicolumn{1}{|c|}{ Name of the tool } & $\begin{array}{c}\text { Number } \\
\text { of answers }\end{array}$ & \multicolumn{1}{|c|}{ Name of the tool } \\
\hline $\mathbf{1}$ & \multicolumn{1}{|c|}{$\mathbf{2}$} & $\mathbf{3}$ & $\mathbf{4}$ \\
\hline 34 & $\begin{array}{l}\text { Google mobile applications } \\
\text { Google calendar, Google Drive, } \\
\text { Google Maps, Google Scholar, } \\
\text { Google Assistant, Gmail) }\end{array}$ & 2 & Library \\
\hline 27 & Electronic calendar & 8 & Paper calendar \\
\hline 22 & Smartphone & 2 & Mind maps \\
\hline 19 & Computer (laptop) & 2 & Social media \\
\hline 21 & Notebook (digital, on smartphone) & 2 & Pendrive \\
\hline
\end{tabular}




\begin{tabular}{|c|l|c|l|}
\hline 1 & \multicolumn{1}{|c|}{2} & 3 & \multicolumn{1}{|c|}{$\mathbf{1}$} \\
\hline 15 & $\begin{array}{l}\text { Mobile applications (banking, he- } \\
\text { alth, weather, time management, } \\
\text { list of tasks / responsibilities, } \\
\text { email, for collective work) }\end{array}$ & 2 & Reminders on the phone \\
\hline 9 & Data cloud & 2 & SIRI \\
\hline 6 & Planner & 2 & Tablet \\
\hline 10 & Electronic mail & 2 & USOS \\
\hline 6 & Public transportation websites & 2 & Computer folders \\
\hline 5 & Web search engines & 1 & Alexa \\
\hline 4 & Applications (generally) & 1 & Calculator \\
\hline 4 & Internet & 3 & Sticky notes \\
\hline 4 & Instant messagers & 1 & Messenger \\
\hline 5 & Facebook & 1 & Navigation \\
\hline 3 & Newsletters & 1 & Graphic programs \\
\hline 3 & MS Office & 1 & Smartwatch \\
\hline 3 & Operating systems (Windows 8.1, & 1 & Habitica \\
\hline 3 & Android, Linux) & 11 & Other \\
\hline
\end{tabular}

The list presented in Table 3 contains the names of tools which the respondents do not use for various reasons (the diagnosis of this issue was not the subject of the study). It should be emphasized that all tools and services seem to be generally well-known and that the respondents are aware of the rules of their functioning, all the more that their names have been precisely given. The decision not to use them may result from the lack of conviction about their functionality or the participants' attachment to alternative methods of managing personal information.

Tab. 3. The list of tools for personal information management unused but known by respondents $(\mathrm{N}=67)$; the respondents could give more than one answer

\begin{tabular}{|c|l|c|c|l|c|}
\hline No. & \multicolumn{1}{|c|}{ Name of the tool } & $\begin{array}{c}\text { Number } \\
\text { of } \\
\text { answers }\end{array}$ & No. & \multicolumn{1}{|c|}{ Name of the tool } & $\begin{array}{c}\text { Number } \\
\text { of } \\
\text { answers }\end{array}$ \\
\hline $\mathbf{1}$ & \multicolumn{1}{|c|}{$\mathbf{2}$} & $\mathbf{3}$ & $\mathbf{4}$ & $\mathbf{5}$ & $\mathbf{6}$ \\
\hline 1 & EndNote, Evernote & 7 & 26 & Google Pay & 1 \\
\hline 2 & Data Cloud f.i.Dropbox & 6 & 27 & Blik (payment system) & 1 \\
\hline 3 & $\begin{array}{l}\text { References managers (f.i.. } \\
\text { Mendeley, Biblioscape) }\end{array}$ & 6 & 28 & E-book reader & 1 \\
\hline 4 & Mind map & 5 & 29 & Dictaphone & 1 \\
\hline 5 & $\begin{array}{l}\text { Voice synthesizer (Alexa, } \\
\text { SIRI) }\end{array}$ & 5 & 30 & $\begin{array}{l}\text { Media and information moni- } \\
\text { toring companies }\end{array}$ & 1 \\
\hline
\end{tabular}




\begin{tabular}{|c|c|c|c|c|c|}
\hline 1 & 2 & 3 & 4 & 5 & 6 \\
\hline 6 & Google Assistant & 4 & 31 & Photoshop & 1 \\
\hline 7 & Google Calendar & 5 & 32 & Google Analytics & 1 \\
\hline 8 & $\begin{array}{l}\text { Collaborative work tools (f.i., } \\
\text { Trello, Asana) }\end{array}$ & 4 & 33 & Ibuk Libra (e-book platform) & 1 \\
\hline 9 & Public transportation apps & 3 & 34 & $\begin{array}{l}\text { Calibration of multiple devi- } \\
\text { ces with one account }\end{array}$ & 1 \\
\hline 10 & Time management apps & 3 & 35 & Metasearch engine & 1 \\
\hline 11 & Calendars & 4 & 36 & Google tools & 1 \\
\hline 12 & To-do lists (f.i. Google Keep) & 9 & 37 & Notebook & 1 \\
\hline 13 & Mobile apps & 2 & 38 & NUKAT (the union catalogue) & 1 \\
\hline 14 & Bibliographies online & 2 & 39 & Microsoft Office & 1 \\
\hline 15 & Library catalogues & 2 & 40 & $\begin{array}{l}\text { Planning the posts on Face- } \\
\text { book }\end{array}$ & 1 \\
\hline 16 & MS Onenote & 2 & 41 & LinkedIn portal & 1 \\
\hline 17 & MS Outlook & 2 & 42 & $\begin{array}{l}\text { Notifications, alarms in the } \\
\text { phone }\end{array}$ & 1 \\
\hline 18 & Twitter & 2 & 43 & $\begin{array}{l}\text { Programs that remember } \\
\text { passwords }\end{array}$ & 1 \\
\hline 19 & Google Survey & 1 & 44 & Tablet & 1 \\
\hline 20 & Library apps & 1 & 45 & Timetable & 1 \\
\hline 21 & Archives & 1 & 46 & Infobroker services & 1 \\
\hline 22 & Public databases & 1 & 47 & $\begin{array}{l}\text { Expense management appli- } \\
\text { cations }\end{array}$ & 1 \\
\hline 23 & Digital libraries & 1 & 48 & Tasks management system & 1 \\
\hline 24 & Ticket-o-mate & 1 & 49 & SVN (Subversion) & 1 \\
\hline 25 & Files management systems & 1 & 50 & Other & 4 \\
\hline
\end{tabular}

A total number of 114 responses was received for the last question, in which the participants of study were asked to indicate tools useful in the field of LIS and related to PIM. The collected data was subject to qualitative interpretation, which involved categorizing the proposed solutions, presenting the given examples and their more general representation. The analysis sought to preserve both the style and intention of respondents' statements translated from Polish to English. Fourteen main thematic categories have been identified, some of them divided into further subcategories. Quantitative characteristics of the responses have been presented in Table 4. Most of the proposals has been listed in the category of "sources of information" - 37 responses, as well as in the field of "automation of libraries" - 18 and generally understood technologies - 15 responses. Slightly fewer proposals have been listed as regards software, natural language processing and Semantic Web - nine, eight, and seven responses respectively. Proposals in the categories of augmented reality, digitization, media monitoring and publishing automation have been submitted no more than five times. 
Tab. 4. Areas of LIS worth of implementing PIM tools - categorized answers of respondents; the respondents could give more than one answer

\begin{tabular}{|l|c|}
\hline \multicolumn{1}{|c|}{ Category } & Number of answers \\
\hline Sources of information & 37 \\
\hline Library automation & 18 \\
\hline Technologies & 15 \\
\hline Software & 9 \\
\hline Natural language processing & 8 \\
\hline Semantic Web & 7 \\
\hline Information verification & 5 \\
\hline Artifical intelligence & 4 \\
\hline Digitization & 3 \\
\hline Media monitoring & 3 \\
\hline Education & 2 \\
\hline Publishing automation & 1 \\
\hline Simultaneus translation & 1 \\
\hline Time management support & 1 \\
\hline Total & 114 \\
\hline
\end{tabular}

In the case of LIS areas where PIM is worth implementing, the highest number of responses referred to the sources of information. Respondents suggested solutions concerning applications, databases, tools of natural language processing, open access, optimization and organization of information and the creation of a platform for managing sources of information. New "tools to facilitate bibliography creation", applications offering access to digital libraries, the creation of an "online database containing a collection of information in the field of LIS with the possibility for registering and logging on of the user surfing in the database" and a "database containing all online bibliographies in all categories instead of a few separate databases available on the Internet" were in demand. Emphasis was also placed on the quality of information sources, postulating the creation of tools "to search for primary sources of information", "generally available expert systems" and "tools to organize information" together with raising the awareness of their functionality. Respondents also expected services facilitating open access, allowing "a wider use of online resources, without any problems related to copyright". This category also included an idea of a "tool for searching for email addresses". With regard to sources of information, suggestions have been made for the development of specialized platforms and for new organization of information. According to the respondents, it would be desirable to have a "platform - a database of knowledge about the Polish publishing market, which would contain information for instance about new publications of individual publishers, information about particular trade events, e.g. fairs with the possibility of immediate registration to them, a "universal catalogue containing all publications from all other catalogues", or a "website where information professionals are logged in and receive a request for information on a given 
topic and then provide it (against payment)". Many responses concerned improving the functioning of libraries. Respondents proposed solutions that would both facilitate access to the library's resources and enable more efficient use of these resources, e.g. the creation of "a library application with all the library content collected so that it can be borrowed and returned via the application", or functionalities such as "the settlement of library fees from the library user's account" or the development of "an application enabling direct contact between the user and the on-duty librarian".

The proposals for new software and improvements to existing technological solutions which would make it easier for users to manage information and access knowledge were classified under the category of "technologies". Exemplary proposals: "ebooks with a Braille reading option, e.g. a screen would form a 'bulge' in the appropriate shape", a "specialized search engine providing information in a more detailed way being at the same time easy to use" or "a market for intelligent systems that will intuitively accommodate to the user should be developed, as this will help to facilitate the search for information".

In the category of software, respondents also proposed several information management solutions. Some concerned the optimization of the existing software, such as "latex or bibtex with a convenient graphical user interface (GUI) and macros support" and "a plugin or modification to Messenger application programming interface (API) facilitating the transfer of files on mobile devices (without the need for compression)". Other responses suggested new functionalities, such as "computers that display data adequately up to the user's fatigue level (example from Overloaded Mind software)" or "Project Management Platform in scrum/agile methodology".

Responses recorded in the study were also related to the use of NLP technology, which, as the results indicated together with the literature analysis conducted earlier, was subject to increasing social demand. The study proposed the following solutions in this area: "voice search in libraries", "glasses that have the ability to connect headphones and convert text to voice by some kind of speech synthesizer" and "an application that would enable the processing of passwords from natural language to information and search language, enabling users to use specialized databases and catalogues".

The further development of the Semantic Web would be equally welcomed; ranging from simpler proposals: "searching for an item with specific phrases rather than using keywords or tags" or solutions known from online shops - "entering a single account into all nonscientific libraries and displaying from an account/user level - you may like it judging on the basis of previously borrowed items" to the use of information technology "based on preferences and already [previously] known content".

Respondents also noticed an increasing role of LIS practitioners and researchers in the assessment of quality and verification of information. They suggested in this area: "a system that takes notes from a given text taking into account only the information that is needed by the user", "software that could be used to verify selected data, available to individual users", or "servers that would filter and remove false and untrue information from the network with the assistance of specialists". A similar participation of specialists in terms of tasks could also apply to media monitoring. Respondents suggested creating "accessible/open software for media monitoring", "creating professional applications that allow monitoring the Internet, with the emphasis on micro-entrepreneurs", as well as "monitoring websites in terms of users' informational behavior". 
LIS practitioners and researchers should also be interested in augmented reality technologies. Respondents proposed to create a "map of thoughts in augmented reality" in this field, to take a virtual tour of the library, and to transfer libraries to virtual reality - "compiling of libraries into a virtual reality, which will offer the possibility of tangible contact with the collections of libraries without the need to leave home".

In terms of digitization, respondents proposed "a full digitization of all scientific studies in progress" and involving "into digitization all users of a given tool". Furthermore, the role of specialists in educating on new technologies and innovative tools has also been recognized. They should "practice and develop ICT skills at the level of school education, which will facilitate the information market, searching for qualitative information and selecting the data collected", and they should also create "information management services visually and linguistically adapted to young people".

Individual responses also suggested the need for LIS practitioners and researchers in the field of publishing automation, introduction of simultaneous translation technology and time management support.

\section{Conclusions}

The research has shown a high understanding of the tools (platforms, solutions, services, devices) used for personal information management. We might also observe that the degree of use of PIM tools is high.

A list of professions whose representatives are expected to take responsibility for verification of information and elimination of fake news is constantly evolving. Discipline professionals have much to offer in providing reliable, convenient, understandable and modern information. Individual information users still expect information that is reliable, easy to use and verified, accessible via new media and applications.

Qualitative analysis of the responses received in the study regarding the tools useful in the field of book, LIS, and connected with PIM showed high expectations of respondents regarding solutions that can be offered by LIS practitioners and researchers in the field of PIM. As we may notice, some of them have already been correctly diagnosed by the environment. Initiatives in the field of open access, digitization of collections, modernization of integrated library systems or ICT education are already being implemented. Others still may provide inspiration. This applies especially to those proposals combining various functionalities, facilitating the use of already operating platforms or changing the existing understanding of the use of information in areas of applications, databases, natural language processing, open access, optimization and organizing and managing an information. The full answer to the research aim was presented in Findings section.

At the same time, however, libraries and information professionals, as bodies invited to participate in the technological revolution, are primarily perceived as entities offering high-quality, verified and truthful information accessible through applications, digital platforms and other modern technological solutions. 


\section{Acknowledgements}

The author sincerely thanks the reviewers and Professor Barbara Sosińska-Kalata, the editor in chief of the journal ZIN - Information Studies, for their valuable suggestions and comments to improve the article.

\section{References}

Barreau, D. (2008). The Persistence of Behavior and Form in the Organization of Personal Information. Journal of the American Society for Information Science E Technology, 59(2), 307-317, http:// doi.org/10.1002/asi.20752

Batorowska, H. (2018). Indywidualne zarządzenie informacją zabezpieczeniem przed manipulacją w środowisku płynnej inwigilacji. Edukacja-Technika-Informatyka, 23(1), 135-143.

Bellotti, V., Ducheneaut, N., Howard, M., Neuwirth, C., Smith, I. (2002). Innovation in Extremis: Evolving an Application for the Critical Work of Email and Information Management. In: Proceedings of the 4th Conference on Designing Interactive Systems: Processes, Practices, Methods, and Techniques (DIS'02) (181-192). New York: Association for Computing Machinery. http://doi. org/10.1145/778712.778740

Bernstein, M., Van Kleek, M., Karger, D., Schraefel, M.C. (2008). Information Scraps: How and Why Information Eludes Our Personal Information Management Tools. ACM Transactions on Information Systems, 26, 1-46, http://doi.org/10.1145/1402256.1402263

Carter, T. M., Levine-Clark, M. (2013). ALA Glossary of Library and Information Science. 4th ed. Chicago: ALA Editions.

Case, D.O., Given, L.M. (2016). Looking for Information: A Survey of Research on Information Seeking, Needs and Behavior. 4th ed. Bingley, UK: Emerald Group Publishing Ltd.

Cate, F.H. (2010). Protecting Privacy in Health Research: The Limits of Individual Choice. California Law Review, 98(6), 1765-1803, http://doi.org/10.15779/Z38J988

Courtright, C. (2007). Context in Information Behavior Research. Annual Review of Information Science and Technology, 41(1), 273-306, http://doi.org/10.1002/aris.2007.1440410113

Cushing, A. (2010). Highlighting the Archives Perspective in the Personal Digital Archiving Discussion. Library Hi Tech, 28(2), 301-312, http://doi.org/10.1108/07378831011047695.

Gonzáles-Alcaide G., Castelló-Cogollos L., Navarro-Molina C., Aleixandre-Benavent R., Valderrama-Zurián J.C. (2008). Library and Information Science Research Areas: Analysis of Journal Articles in LISA. Journal of the American Society for Information Science and Technology, 59(1), 150-154.

Jones, W. (2007). Personal Information Management. Annual Review of Information Science and Technology. 41(1), 453-504, http://doi.org/10.1002/aris.2007.1440410117

Jones, W., Teevan, J., eds. (2007). Personal Information Management. Seattle, London: University of Washington Press.

Julien, H., Duggan, L.J. (2000). A Longitudinal Analysis of the Information Needs and Uses Literature. Library E Information Science Research, 22(3), 291-309, http://doi.org/10.1016/S07408188(99)00057-2

Landsale, M. W. (1988). The Psychology of Personal Information Management. Applied Ergonomics. 19(1), 55-56, http://doi.org/10.1016/0003-6870(88)90199-8

Marx, G. (2007). Privacy and Social Stratification. Knowledge, Technology \& Policy, 20(2), 91-95, http://doi.org/10.1007/s12130-007-9009-5

Materska, K. (2008). Modelowe koncepcje informacji naukowej (information science) w XXI wieku. In: K. Materska, E. Chuchro, B. Sosińska-Kalata (eds.). Organizowanie środowiska informacji $i$ wiedzy (19-40). Warszawa: Wydaw. SBP. 
Materska, K. (2012). Wymiary zarządzania informacją indywidualną. In: B. Sosińska-Kalata, E. Chuchro (eds.). Spoteczeństwo i sieć informacyjna (65-79). Warszawa: Wydaw. SBP.

Mollick, J.S. (2010). Determinants of Perceived Trustworthiness in Managing Personal Information. International Journal of the Academic Business World, 4(1), 19-28.

Sapa, R. (2014). Wsparcie dla indywidualnego zarządzania informacją w polskich repozytoriach uczelnianych. In: A. Korycińska-Huras, M. Janiak (red.), Komunikacja naukowa w środowisku cyfrowym: badania, zasoby, użtkownicy (81-96). Warszawa: Wydaw. SBP.

Sapa, R. (2016a). Projektowanie badań indywidualnego zarządzania informacją z zastosowaniem techniki oprowadzania (guided tour). In: S. Cisek (ed.). Inspiracje i innowacje: zarzadzanie informacją w perspektywie bibliologii i informatologii (95-108). Kraków: Biblioteka Jagiellońska.

Sapa, R. (2016b). Metodologia badań indywidualnego zarządzania informacją: wybrane aspekty. Zagadnienia Informacji Naukowej, 54(1), 7-20.

Shah, C. (2017). Social Information Seeking: Leveraging the Wisdom of the Crowd. Springer International Publishing, http://doi.org/10.1007/978-3-319-56756-3

Sosińska-Kalata, B. (2007). Współczesne oblicze nauki o informacji w Polsce i za granicą. In: E. Gondek, D. Pietruch-Reizes (eds.). Studia z informacji naukowej i dyscyplin pokrewnych (93-119). Katowice: Wydaw. Uniwersytetu Śląskiego, 93-119.

Sosińska-Kalata, B. (2016). Indywidualna organizacja wiedzy: pojęcia, problemy badawcze, stan badań i ich perspektywy. Praktyka $i$ Teoria Informacji Naukowej $i$ Technicznej 16 (4), 3-21.

Stenmark, D., Espenkrona, K., Svensson, M. (2010). Design Implications for Personal Information Management: A Theoretical Evaluation of a Prototype Interface [online]. Proceedings of the Sixteenth Americas Conference on Information Systems, Lima, Peru, August 12-15, 2010 [10.11.2019], https://gup.ub.gu.se/file/95871

Świgoń, M. (2012). Zarzadzanie informacja i wiedza: podstawy teoretyczne, badania w wymiarze indywidualnym, Olsztyn: Wydaw. UWM.

Thint, M., Case, S., Azarmi, N., Azvine, B., Hare, S. (2003). Personal Information Management Assistants - From Research to Commercialization. BT Technology Journal, 21 (4), 39-43, http:// doi.org/10.1023/A:1027371101870

Tomaszczyk, J. (2008). Zarządzanie informacją w nauce, In: D. Pietruch-Reizes (ed.). Zarzadzanie informacją osobistą (134-146). Katowice: Wydaw. Uniw. Śląskiego.

\title{
Co bibliologia i informatologia mogą zaoferować $\mathrm{w}$ zarządzaniu indywidualnym informacją?
}

\begin{abstract}
Abstrakt
Cel/Teza: Rozwój zarządzania informacją indywidualną (personal information management, PIM) wskazuje nowe pole badawcze dla teoretyków i praktyków z zakresu bibliotekoznawstwa i informacji naukowej. W artykule prześledzono zastosowanie rozwiązań technicznych w zakresie PIM w bibliotekoznawstwie i informacji naukowej.

Koncepcja/Metody badań: W przedstawionych badaniach wykorzystano krytyczną analizę literatury, aby wyjaśnić związek między PIM a bibliotekoznawstwem i informacją naukową oraz przygotować badanie empiryczne skoncentrowane na postrzeganiu przydatności narzędzi PIM w obszarze praktyki i badań bibliotekoznawstwa i informacji naukowej. Badanie empiryczne przeprowadzono przy użyciu metody mieszanej, obejmującej metody zarówno badań ilościowych, jak i jakościowych.

Wyniki i wnioski: Przeprowadzona analiza wykazała, że rozwiązania proponowane przez teoretyków i praktyków bibliotekoznawstwa i informacji naukowej w zakresie PIM zostały dotychczas poprawnie
\end{abstract}


zdefiniowane. Niektóre inicjatywy z zakresu otwartego dostępu, digitalizacji kolekcji, unowocześnienia zintegrowanych systemów bibliotecznych czy zastosowań technologii informacyjno-komunikacyjnych w edukacji zostały już skutecznie wdrożone. Jednakże teoretycy i praktycy z zakresu bibliotekoznawstwa i informacji naukowej postrzegani są przede wszystkim jako oferujący rozwiązania oparte na wysokiej jakości, zweryfikowanej i rzetelnej informacji, dostępnej przez aplikacje mobilne, platformy cyfrowe oraz inne nowoczesne rozwiązania technologiczne.

Oryginalność/Wartość poznawcza: Omówione wyniki badania mogą stanowić inspirację dla teoretyków i praktyków bibliotekoznawstwa i informacji naukowej do dalszego rozwijania oferty ich instytucji.

\section{Słowa kluczowe}

Informacja naukowa i bibliotekoznawstwo. Oczekiwania studentów. Zarządzanie informacją indywidualną.

ZBIGNIEW GRUSZKA, PhD, is Assistant Professor at the Department of Information, Library and Book Science, Faculty of Philology, University of Lodz, Poland. His research interests are local communities, ICT, and library management. Selected publications: How to Make New in the Age of Competition? Creating New Education Offer in the Field of Information Science in Poland on the Example of the University of Lodz (2018, co-author: M. Antczak; published in T. Aparac-Jelušić et al. (eds.), The Future of Education in Information Science); Kryterium dostępności jako wskaźnik jakości. Model rozproszony bibliotekarstwa publicznego na przykładzie łódzkich bibliotek (2017, published in: M. Wojciechowska (ed.) Zarządzanie jakością w bibliotece. Warszawa); Lektury „wypędzonych”. Książka na łamach czasopisma „Waldenburger Heimatbote" w latach 1949-2013 (2017, published in: B. Iwańska-Cieślik, E. Pokorzyńska (eds.) Dzieje książki i prasy: przegląd badań za lata 2013-2015).

Contact to the Author:

zbigniew.gruszka@uni.lodz.pl

Department of Information, Library and Book Science

University of Lodz

Pomorska 171/173

90-236 Łódź 